\title{
MULTIDIMENSIONAL AND EQUIVOCAL: the Theoretical and Philosophical IsSUES OF LEgal SANCTIONS
}

\author{
Anna Kociołek-Pęksa \\ Department of Law, Faculty of Civil Safety Engineering, \\ Main School of Fire Service in Warsaw \\ apeksa@sgsp.edu.pl \\ Władysław Pęksa \\ Jagiellonian University, Chair of Polish Legal \\ History, Faculty of Law and Administration \\ wladyslaw.peksa@uj.edu.pl
}

KOCIOŁEK-PĘKSA, Anna; PĘKSA, Władysław. Multidimensional and Equivocal: the Theoretical and Philosophical Issues of Legal Sanctions. International and Comparative Law Review, 2017, vol. 17, no. 2, pp. 73-92. DOI 10.2478/iclr2018-0016.

Summary: The social order, and especially the legal order, is implemented and maintained by institutions whose actions are based on the application of various forms of legal constraint. A sanction in the law may take various forms, as diversified in content may be the legislative justifications for them. The article deals with reflection on sanctions. It begins with a linguistic note: "sanction" as a semantic category and a term from juristic language. Then in the theory of law as an element of the structure of the norm. Authors also point out that sanctions exist in normative systems other than the law and they start reasoning by citing the view that the most important goal of establishing sanctions is to prompt adequate motivation of the subjects to comply with the norm (legal or other). In the essential part of the article the authors refer the division and typology of sanctions and theirs construction. In the final and most important part of the article the classical point of view - quoted at the beginning - is confronted with the order of international law, which is sometimes recognized as as lex imperfecta - as the international public law (law of nations) hasn't developed a system of institutionalized sanctions ensuring observance of its norms. The authors suggest that it is a mistake committed the most frequently by lawyers not expert in international public law unjustifiably and incorrectly transfer the apparatus of notions with precisely assigned significance straight from the theory of domestic (in this case, Polish) law into the sphere of research on public international law. For the international law is shaped as a decentralized structure, within which the question of the execution of behaviours complying with its principles and rules belong to the duties of the subjects of that law-members of international society. The effectiveness, efficiency and purposefulness of the law is not completely 
nor exclusively conditioned by the existence and type of legal constraint and the international law has not been deprived of the attribute of law. The only real thing is only that a sanction has not always been automatically and immediately applied in case of infringement of a legal duty, since launching a sanction may require a specific legal action on behalf of another entitled subject of international law.

Keywords: Legal sanction, lex imperfectae, normativism, regulatory influence of the legal norm, three-part structure of the legal norm, imperfect norm, coupled norms, sanctioned norm, sanctioning norm, legal constraint, effectiveness of the law, efficiency of the law, reinforcement/weakening of the regulative impact.

"Science attempts to produce one, the most logically unified legal system, even if the normative facts themselves were opposed to it; it attempts to fill in the gaps in the system, to remove contradictions, in one word, to perform this "digging at the rotten tree" - and all of it to make the pattern of due behaviour given to people, to be unified and monopolistic",

LANDE, Jerzy. Studia z filozofii prawa, Warszawa: Państwowe Wydawnictwo Naukowe, 1959, p.425.

\section{Introduction.}

In the contemporary international community, among societies, and in other politically organised collectives that cannot be narrowed down only to states-if only because of the existence of such objects as international organisations-the social order, and especially the legal order, is implemented and maintained by institutions whose actions are based on the application of various forms of legal constraint. In the research on legal sanctions in legal orders, the departure point will be the conviction that the comprehension of legal norms as a certain enunciation of accompanying psycho-social situations (sanctions) allows for theoretical research ${ }^{1}$. A sanction in the law may take various forms, as diversified in content may be the legislative justifications for them ${ }^{2}$. This is why examination of the problem of sanctions is not, as it may seem prima facie, simple nor unidimensional.

This reflection on sanctions ${ }^{3}$ should begin with a linguistic note. In Latin, the word for "sanction"-in its meaning defined as juridical-signifies a conse-

1 See: OPAŁEK, Kazimierz. Z zagadnień teorii prawa i teorii nauki Leona Petrażyckiego: studia opracowane dla upamiętnienia stulecia urodzin. Warszawa: Państwowe Wydawnictwo Naukowe, 1969, p. 54.

2 The same opinion is shared by: SEIDLER, Grzegorz, GROSZYK, Henryk, PIENIĄŻEK, Antoni. Wprowadzenie do nauki o państwie i prawie. LUBLIN: Wydawnictwo UMCS, 2003, p. 128.

3 In the dictionary Stownik socjologii i nauk społecznych, we can find a joined definition of "sanction" and "social sanction", which should be understood as "every mean supporting the conformism towards socially acclaimed standards. Sanctions can be positive (when 
quence of infringing the law. It needs to be noted here that the term "sanction" is used in the professional literature to designate the consequence of infringing not only legal norms but also other social norms, both in the state space and within the international community ${ }^{4}$. "Sanction" as a semantic category is a term from juristic language while in the theory of law, that is, at the highest rank of theoretical generalization, a legal sanction is treated as a separate norm or as an element of its structure ${ }^{5}$.

Legal sanctions (both negative and positive) and non-legislative sanctions existing in normative systems other than the law (such as social subsystems) operate in a formalized manner in the case of the law, or in a non-formalized way in other normative systems, as they are intentionally treated as a tool of legal control and social control. According to Andrzej Kojder, "in every society, there is a more or less sophisticated system of control over the behaviour of individuals and collectives that is composed of a sum of different manners of supervision and regulation of human behaviour in situations acclaimed to be socially important". For that very reason, we consider in our research that sanctions comprise one of the most important indicators (motivating factors: behavioural and finite) of the effective conduct/behaviours of individuals, social groups, societies and politically organised collectives and are justified both in a cognitive as well as a social and juristic-pragmatic dimension.

\section{The idea of legal sanction in the structure of legal system.}

A legal sanction is purely external; it relies on the credibility of the external authority to use force to impose submission to the $\mathrm{law}^{7}$. A sanction treated as

rewarding a behaviour complying with the general expectations) or negative (when penalizing various forms of behaviour drifting away from the norm), as well as formal (as in legal sanctions) or informal (as in hurling insults). The last type of sanction is sometimes called 'informal social control”', MARSHALL, Gordon, TABIN, Marek (eds.). Stownik socjologii i nauk społecznych. Warszawa: Państwowe Wydawnictwo Naukowe, 2008, pp. 299-300.

4 About basic sense of sanction see in GARNER, Bryan (ed.). Black's Law Dictionary. Ninth edition. United States: WEST A Thomson Reuters business, 2009, pp.1458-59. Moreover see in polish literature: DZIEDZIAK, Wojciech. Sankcje prawne. In SOKÓŁ, Wojciech, DZIEMIDOK-OLSZEWSKA, Bożena. Encyklopedia politologii. Vol. 2 Instytucje i systemy polityczne. Warszawa: Oficyna a Wolters Kluwer business, 2012, pp. 357-359. See also CESARZ, Zbigniew. Sankcje międzynarodowe. In ŁOŚ-NOWAK, Teresa, FLORCZAK, Agnieszka (eds.). Encyklopedia politologii. Tom V Stosunki Międzynarodowe. Warszawa: Oficyna Wolters Kluwer business, 2010, s. 537-539.

5 GRYNIUK, Anna. Sankcja prawna a prawny przymus. In SKĄPSKA, Grażyna, CZAPSKA, Janina, DANIEL, Krystyna, GÓRSKI, Jakub, PAŁECKI, Krzysztof (eds.). Prawo w zmieniającym się społeczeństwie. Księga Jubileuszowa Profesor Marii Boruckiej-Arctowej. Kraków: Wydawnictwo Adam Marszałek i Uniwersytet Jagielloński, 1992, p. 93.

6 KOJDER, Andrzej. Godność i siła prawa. Warszawa: Oficyna Naukowa, 2001, p. 307.

7 Such an understanding of "sanction" was in use at least from J. Bentham's times. For more, see: DUTKIEWICZ, Paweł. Powinności i sankcje. In Etyka zarys. Kraków: Uniwersytet Jagielloński. Instytut Filozofii. Zakład Etyki. Wydawnictwo Uniwersytetu Jagiellońskiego 
repression serves to maintain the social order in the same way and on the same basis as normative systems in their task to guarantee a given social and legal order$^{8}$. The problem with using repression in contemporary democratic societies, especially when it comes to justifying the punitory right, is quite controversial in the judicial and philosophical literature ${ }^{9}$. Legal norms distinguish themselves through the element of constraint (sanction), which, as noted by Jerzy Wróblewski, according to normativism is included in the content of the norm and not to the sphere of facts. This means the law and state apparatus of constraint have nothing in common from a normativism point of view ${ }^{10}$. The main function of normativism is to implement standards independent of individual convictions and which are the grounds for the right to order, prohibit or author$i^{11}{ }^{11}$. The very sanctions established by a legislature (sanctions as a normative concept) don't by themselves enforce the effectiveness of legal norms as legal sanctions constitute only one factor influencing the effectiveness of the law ${ }^{12}$. Zygmunt Ziembiński claimed that in order to shape the conduct of an addressee of the law regarding a standard of due behaviour comprised in the disposition of a legal norm (that is, the addressee will decide to observe the legal norm when properly informed) and by doing so to avoid the negative effects described in the sanction of the legal norm, it is necessary for the addressee to endorse the content of the norm or to be afraid of the sanction threat if trespassing the norm, or for the conduct prescribed by the norm to become the addressee's habit ${ }^{13}$-ideally the standard of due conduct should be internalized in the process of normative socialization. Thus, the psycho-sociological element, that is, legal awareness of the law's addressees, determines (however, not automatically nor exclusively) the range and means of implementing a legal sanction without making a distinction between an understanding of the very sanction as linguistic enunciation or as experience (a type of ethical emotion), or as a sovereign's or any other authority's order. Besides, within the above-mentioned range of the study on the function and role of a sanction, on the notion of "sanction" as a component of a legal norm, four definitions of legal norms may be referred, as indicated by Jerzy Wróblewski: 1) judgment about duty, 2) the will of the state, 3) semantic outline, and 4) evaluation ${ }^{14}$. Evidently, the outcome will be identical with the

w Krakowie, 1992, p. 27.

8 See: GRZYBOWSKI, Stefan. Dzieje prawa. Opowieść, refleksje, rozważania. WrocławWarszawa-Kraków: Wydawnictwo Zakład Narodowy im. Ossolińskich,1981, p. 221.

9 See: DUFF, Antony. Karanie obywateli. "Ius et Lex" 2006, No. 1, p. 21 and following.

10 WRÓBLEWSKI, Jerzy. Krytyka normatywistycznej teorii prawa i państwa Hansa Kelsena. Warszawa: Państwowe Wydawnictwo Naukowe, 1955, pp.148-149.

11 BROŻEK, Bartosz, BROŻEK, Anna, STELMACH, Jerzy. Fenomen normatywności. Kraków: Copernicus Center Press, 2013, p. 21.

12 See: DZIEDZIAK, Wojciech. Wpływ sankcji prawnych i moralnych na skuteczność prawa. „Studia Iuridica Lublinensia” Vol. XXIV, 1, 2015, pp. 67 and 72.

13 ZIEMBIŃSKI, Zygmunt. Problemy podstawowe prawoznawstwa. Warszawa: Państwowe Wydawnictwo Naukowe,1980, p. 423.

14 WRÓBLEWSKI, Jerzy. Krytyka normatywistycznej teorii prawa..., op.cit.,p.133. 
above, that is, it will not influence the fact of the direct and indirect-clearly, on a limited scale-impact (in the sense of indicating and determining) on the volitional, motivational and decisive processes of the addressees of the law in the context of fulfilling or neglecting the legal duties. We assume, then, that legal awareness of the law's addressees within the existence of a sanction constitutes an extra guarantee for ensuring the observance of the otherwise binding norm, as the sanction is only an additional element (one of three), not the only one, and not even the strongest or most efficient among the guarantees of effectiveness of the observance of a binding law ${ }^{15}$.

An essential goal of establishing sanctions is to prompt adequate motivation of the subjects to comply with the legal norm ${ }^{16}$. Of this opinion is Andrzej Kojder, who believes that by means of legal sanctions it is possible to influence, in a rather effective, purposeful and planned manner, individual and collective behaviours; he also affirms that the creation and application of the law makes it possible to affect public opinion in a way that motivates observation of the law ${ }^{17}$. Thanks to that, it is possible to effect the addressees' factual choices in their observance of the law and their fulfilment of the goals of the legal regulation assumed by the legislature, which is particularly important due to the key ${ }^{18}$ role of the law in the accomplishment of fundamental social goals.

It is indicated ${ }^{19}$ in the philosophy of law and the philosophy of politics that theoretical justification, or social legitimization for the right of punishment would be a concept, defined by Ronald Dworkin, as an imaginary assembly that is an epiphenomenon of the theory of the social contract, according to which individuals assume obligations and submit themselves to the right of punishment limiting their individual freedom ${ }^{20}$. The law's addressees are little aware of the fact that by accepting to receive sanctions, including the use of repression, they de facto adopt the view that a sanction is an expression of constraint as

15 Similar: IZDEBSKI, Zygmunt. Teoria państwa i prawa. Warszawa: Akademia Teologii Katolickiej, 1975, p. 174.

16 Statement formulated already in the 1970s, during the previous legal and political system in Poland, by Zygmunt Izdebski. Same author: Teoria państwa i prawa. op.cit, p. 74.

17 KOJDER, Andrzej. Godność i siła prawa. op.cit., p. 309.

18 Representatives of the current of economic analysis of the law R. Cooter R. and T. Ulen draw our attention to this aspect of the law, pointing to the fact that the economy as a social science brings into the legal science extremely useful normative standards that facilitate the valuation of both the law and the effectiveness of political activity. See: COOTER, Roger, ULEN, Thomas. Law and Economics. Pearson Addison Wesley, Boston-San Francisco-New York-London-Toronto-Sydney-Tokyo-Singapore-Madrid-Mexico CityMunich-Paris-Cape Town-Hong Kong-Montreal 2008, pp. 3-5).

19 For example, see: PENO, Michał. Filozoficzne podstawy karania-uzasadnienie istnienia kary we współczesnych społeczeństwach demokratycznych. In: NAWROT, Oktawian, SYKUNA, Sebastian, ZAJADŁO, Jerzy (eds.). Konwergencja czy dywergencja kultur i systemów prawnych. Warszawa Wydawnictwo CH Beck, 2012, pp. 243-250.

20 DWORKIN, Ronald. Biorac prawa poważnie. Warszawa: Państwowe Wydawnictwo Naukowe, 1998, p. 277. 
a constitutive feature of the law, thus acceptance of the law extends automatically on acceptance of the use of sanctions. It derives, among others, from the fact that while faced with a dilemma about a choice of legally relevant conduct (action, non-action or abandonment), the law's addressee (an actor in public international law), by his seemingly neutral axiological decision as to whether to comply with the standard of proscribed behaviour formulated by the disposition of the legal norm, is in reality faced with a decision about the choice of axiology to follow, if the axiological ground of the legal norm addressing him is not compatible with his preferred scale of values. "The addressee may not oppose that if he considers those orders and interdictions to be justified in the light of his own convictions (justification of the axiology is autonomous) or if he is unclear about the way of conduct to adopt and the legislator by indicating the defined conduct liberates him from nagging doubts by imposing specific values (justification of the axiology is heteronomous)" 21 .

However, although a sanction as a psycho-social matter is generally defined by legal provisions and in the practice of applying the law, a lawyer is interested in "sanction", according to Kazimierz Opałek, not as a psycho-social matter but as a linguistic fact ${ }^{22}$. One cannot, however, examine sanctions correctly without taking into account the evidence underlined by Czesław Znamierowski that it is most frequently a situation of constraint: the legal norm's addressee has found himself in a legally relevant situation and in front of a choice of behaviour that would lead to future consequences, all of which he considers to be disadvantageous, that is, before the choice of a lesser evil ${ }^{23}$. A legal sanction is institutionalized, which means that its application takes place through institutionalized constraint-one reserved exclusively for the state/subject of international law. This is partly the reason why for sociologists and psychologists who deal with law, but also for some theoreticians, a legal sanction does not constitute solely a linguistic fact/dimension. Anna Gryniuk unequivocally states that legal constraint is a real phenomenon (psychosocial) ${ }^{24}$. Hence, the majority of the theoretical research on legal sanctions is insufficient as it has been conducted by theoreticians and philosophers within the philosophy of the language and theory of law, uncon-

21 REDELBACH, Andrzej, WRONKOWSKA, Sławomira, ZIEMBIŃSKI, Zygmunt. Zarys teorii państwa i prawa. Warszawa: Państwowe Wydawnictwo Naukowe, 1994, p. 90.

22 See: OPAŁEK, Kazimierz. Z zagadnień teorii prawa i teorii nauki Leona Petrażyckiego: studia opracowane dla upamiętnienia stulecia urodzin. Warszawa: Państwowe Wydawnictwo Naukowe, 1969, p. 52.

23 See: ZNAMIEROWSKI, Czesław. Podstawowe pojęcia teorii prawa, cz I Układ prawny i norma prawna. Poznań 1934, p. 61 and following. Moreover see also CZEPITA, Stanisław. Konstrukcje teoretycznoprawne Czesława Znamierowskiego. Poznań: Wydawnictwo Naukowe Uniwersytetu Adama Mickiewicza, 1988.

24 GRYNIUK, Anna. Sankcja prawna a prawny przymus. In SKĄPSKA, Grażyna, CZAPSKA, Janina, DANIEL, Krystyna, GÓRSKI, Jakub, PAŁECKI, Krzysztof (eds.). Prawo w zmieniajacym się społeczeństwie..., op.cit., 1992, p. 93. For more, see by the same author: Przymus prawny: studium socjologiczno-prawne. Toruń: Wydawnictwo Uniwersytetu Mikołaja Kopernika w Toruniu, 1994. 
nected to sociologists and social psychologists; their flaw consists of them being multidisciplinary instead of interdisciplinary.

In the theory of law, the interdependence between sanctions and legal duties is exposed, which underlines and excessively displays negative sanctions as an annoyance put in the form of an institutionalized constraint in case of the lack of or improper fulfilment of a legal duty. Only a few authors point to a sanction as being "a warranty for something that isn't necessarily an infringement of duty" 25 , thus a sanction as the consequence of an addressee's behaviour may be a positive sanction, such as a reward for proper, correct and timely accomplishment of a legal obligation; at the same time, in this context, the existence of norms formulating duties but deprived of sanctions is not excluded (more on the topic further in the text). The dichotomist and disjunctive division of sanctions to positive ones and negative ones bears the effect of the sanction being understood as a reward or punishment, which modifies the definition of an ordered or forbidden behaviour prescribed in the norm. If, however, we extend the field of study of sanctions to normative systems other than the law, but which also operate with sanctions (social sanctions) even though not institutionalized (concentrated), rather dispersed, we notice that in various normative systems (such as religious, moral, customary, ethical, cultural ones) the coexistence of sanctions seen as penalties and rewards, enables the simultaneous functioning of mutually contradictory norms ${ }^{26}$; with the exception of the system of legal norms, where one of the contradictory norms would have to be derogated. Nevertheless, in reference to relations between particular normative systems, a norm of a system A norm from system A may remain in contradiction with a norm of system B, both in its disposition and sanction (the same behaviour may be ordered and rewarded within one system while simultaneously prohibited and penalized in another), and thus, execution of the sanction within one normative order may be authorization (i.e., within a legal system) while within another normative system it will be an order (i.e., religion). The author of the so-called "pure theory" of $\mathrm{law}^{27}$, Hans Kelsen, formulated a standpoint that goes even further: he assumed that even within the same normative system, it is possible to legitimize the functioning of contradictory behaviours ${ }^{28}$, obviously with the reservation that the

25 FILIPEK, Józef. Sankcja prawna w prawie administracyjnym. „Państwo i Prawo” No. 12, 1963, pp. 873-880.

26 For more, see: GREEN, Michael Steven. Hans Kelsen and the logic of legal systems. "Alabama Law Review" Vol. 53 No. 2, 2003, pp. 365-413.

27 It is worthwhile to mention that the "pure theory of law" by Hans Kelsen, in its aspect of the possible explanation of the law as a product of human activity, was undermined by, among others, Jerzy Wróblewski. He claims that "the pure theory of Kelsen not only doesn't explain the state and the law as a product of human activity, but doesn't even formulate this thesis clearly, and what is more, according to its methodology, it cannot formulate it". See: WRÓBLEWSKI, Jerzy, Krytyka normatywistycznej...,op.cit., p. 227.

28 See: KELSEN, Hans. Pure Theory of Law. Berkeley-Los Angeles: University of California Press, 1970, p. 25. 
dispositions of the contradictory norms (norm A foreseeing outcome $\mathrm{X}$, and norm $\mathrm{B}$ foreseeing an outcome other than $\mathrm{X}$ ) cannot be accomplished by the same addressee at the same time, as the order and interdiction concerning the same object cannot be attained by the same behaviour. Kelsen himself considers various aspects of the law as a tool to enforce by the means of sanctions operating on constraint the behaviour desired by the legislature, both on an individual and social level, only to conclude that if the law cannot be anything else but an order of external constraint, it has to be seen as a specific technique of social organization. Kelsen's opinion on this is criticized by Jerzy Wróblewski, who reproaches him that such a construct, having as its purpose "purity" of the theory of law, leads in reality to a situation in which "law as social technique becomes a goal in itself" ${ }^{29}$.

\section{The legal sociology view on the idea of legal sanctions}

The wider consequences of the simultaneous coexistence of not-alwayscoherent nor reconcilable, legal and extra-legal regulations (norms) of the same fragments of the social reality (including the legal reality), operating with sanctions proper for the normative systems (within which they were created/ shaped), are the consequences of the motivation of the addressees of the norms to the correct behaviours. The question is, which of the simultaneously existing normative standards of due conduct will be chosen and carried out. In this field, Krzysztof Pałecki, based on his empiric research ${ }^{30}$, distinguished four reactions of addressees to situations where legal and extra-legal normative regulation appear simultaneously (in parallel). "The first of them could be described as a mono-normative determination. It consists of the fact that members of a given collective follow only one type of norms (bold in original text) while ignoring all the other types of normative regulations, as well as all the other norms regulating the matter in question (...) The second type of reactions would be called dispersion of regulatory influences. It consists of a sort of "division" of a unified matter, regulated in parallel by various types of norms, made by the members of a given collective, into two or more independent, as far as influence on the addressees' conduct is concerned, "spheres of impact" (determination). In each of these "spheres", addressees are guided by different norms without consideration to other regulations. (...) The third type of social reaction will be described as reinforcement of regulatory impact of the law and/or extra-legal social norms. It consists of the addressees guided only by provisions of one type of norm (i.e., legal norms), while referring to the similar-objectively or solely in their view-regulations comprised in other norms in order to have an addi-

29 WRÓBLEWSKI, Jerzy. Krytyka..., op.cit.,p. 140.

30 The author cites research in the field of family law, published in 1978. See: PAŁECKI, Krzysztof, Społeczne opinie o prawie i jego sądowym stosowaniu $w$ dziedzinie stosunków rodzinnych. In BORUCKA-ARCTOWA, Maria. Poglady społeczeństwa polskiego na stosowanie prawa. Wrocław: Wydawnictwo Zakład Narodowy im. Ossolińskich, 1978. 
tional argument to justify the obligation to observe the first norms (fortifying the motivation to obey them). It often happens in the cases regulated by norms belonging to the core of the normative system in the given society. (...) Lastly, the fourth type of reaction to the simultaneous legal and extra-legal regulation of the same matters can be described as weakening of the regulatory impact. In short, it consists of the non-observance of certain norms (legal, extra-legal) or the motivation to obey them being weakened for the reason of confusion experienced by their addressees who were convinced of the contrary regulation set by other norms on the same matter. Obviously, this conviction may be more or less false, but still it can affect negatively the eagerness to obey the norms as the duty has been 'weakened"' 31 . A consequence of the occurrence of various social norms in parallel is obviously similar to the occurrence of sanctions based on which some of the addressees of the norm make decisions as to the choice of optimal (from a subjective point of view) conduct that would lead them in possibly the most effective and efficient manner to the fulfilment of selected values-goals. It's important to note, however, that the type of sanctions that would determine those decisions to the highest degree (concentrated sanction or one of the dispersed sanction) depends on a norm from a given normative order/system from which the sanction internalized by the addressee ${ }^{32}$ derives, and it will be in reference to the axiological fundament of that norm (or defined value) that the process of axiological association will proceed ${ }^{33}$. The assessment procedure plays an essential (rudimentary) part in decision-making processes about the choice of norms of conduct and outline the factual way for their fulfilment, based on the criterion of the value protected by the given norm and the sanction aimed at ensuring the achievement and multiplication of the very value, that is, the sanction as indicator of the finite effectiveness of the norm.

31 PAŁECKI, Krzysztof. Prawoznawstwo zarys wykładu. Prawo w porzadku społecznym. Warszawa: Wydawnictwo Difin, 2003, pp. 182-185.

32 Internalization of the norms is a process of transformation of the heteronomous norms into autonomous norms in the normative awareness of the norm's addressees. See: PAŁECKI, Krzysztof, Prawoznawstwo zarys wykładu..., p. 69. See also: ZIEMBIŃSKI, Zygmunt. Wstęp do aksjologii dla prawników. Warszawa: Wydawnictwo Prawnicze,1990, p. 243 and following.

33 The process of the axiology of association "consists of a gradual coordination (conformation) of the individual axiology of preferences (bold in original text) of an individual hierarchy of values of a person with values determining the regulatory content of the norms; norms imposed on a person in the normative socialization process, from 'outside'. It allows acceptance of certain of these norms, at first 'external' (environmental) for one's own 'internal' norms. This process is not identical to internalisation of the norms". PAŁECKI, Krzysztof. Prawoznawstwo zarys wykładu....,op. cit., p. 67. 


\section{Types of sanctions and constructions and concepts of a legal norm}

The most widespread and, at the same time, fundamental division of sanctions is into three types: repressive sanction (to execute punishment ${ }^{34}$ against one liable for infringement of a law), executive sanction ${ }^{35}$ (applied when achievement of the expected state is still attainable despite infringement of the law), and nullity sanction (to recognize as null from a legal point of view actions that were aimed at achieving an effect but which, because of the incompatibility of the actions with the obligatory legal requirements, do not result in the intended effects) ${ }^{36}$. Also generally accepted is the division of legal norms regarding sanctions on the infringement of dispositions of the norm, considering the criterion of a mutual link between a repressive and executive sanction. As a result of applying such a criterion, we obtain the following distinction: if infringement of the disposition of a repressive or nullity sanction is foreseen, we have to do with so-called leges plus quam perfectae; leges perfectae, by contrast, foresees exclusively annulment of an action non-conforming with the law while leges minus quam perfectae anticipates only a penalty without anticipating annulment; leges imperfectae, lastly, does not foresee sanctions, nullity nor a penalty for infringement of the disposition ${ }^{37}$. This seemingly obvious division is intrinsically related to the problem of the construction of the norm itself and the role that the sanction plays in it.

34 Some authors formulate the opinion that there is no need to justify or legitimise the use of repressive sanctions, especially penal ones. For example, in the textbook of penal law by Julliusz Makarewicz we find the conviction/statement that all the penal theories attempting to justify their penalties seem obviously erroneous, as the penalty does not require justification-unlike the crime, which is a social fact that can at the most be explained, MAKAREWICZ, Juliusz. Prawo karne ogólne. Lwów 1914, p. 27.

35 "Executive sanction" is sometimes called "restoring sanction" (from Latin: restitutio, or return to the previous sate). See: CHAUVIN, Tatiana, STAWECKI, Tomasz, WINCZOREK, P. Wstęp do prawoznawstwa. Warszawa Wydawnictwo CH Beck, 2014, p. 115.

36 See: BORUCKA-ARCTOWA, Maria, WOLEŃSKI, Jan. Wstęp do prawoznawstwa. Kraków: Wydawnictwo Uniwersytetu Jagiellońskiego w Krakowie, 1998. pp 76-77. In reference to the nullity sanction, i.e., in the dogma of civil law, we encounter an argument in favour of the very careful formulation and application of a sanction, as Stanisław Sołtysiński and Andrzej Szlęzak say. Zbigniew Radwański, while analysing the range of the application of Art. 58 of the Polish civil code, postulated reaching for the nullity sanction prudently and he stressed that the "law" comprises all the legal provisions in force together with local law and EU law, excluding from the content of the notion of the law such legal acts as statutes passed by companies, cooperative organisations and other legal persons. Using the concept of conventional actions, he urged limiting the faultiness of the legal action and its absolute nullity when he also agreed with the statement that legal norms comprised in civil code but also in the code of commercial companies, don't offer the bases to distinguish the null actions from "non-existing" actions. See: SOŁTYSIŃSKI, Stanisław, SZLĘZAK, Andrzej. Profesor dr Zbigniew Radwański (1924-2012). „Studia Prawa Prywatnego" No. 7 (annual), Vol. 1(28) 2013, p. 5.

37 For more, see: CHAUVIN, Tatiana, STAWECKI, Tomasz, WINCZOREK, Piotr. Wstęp do prawoznawstwa...op.cit. , pp. 118-119. 
That issue of the construction of the legal norm is crucial in our opinion, since not every legal norm, even those whose dispositions impose on the addressee of the law a necessity to accomplish a legal duty, comprises an element of sanction. The concepts of the construction of the legal norm that appears in the Polish literature on the matter have, respectively, a two- and three-part structure of a legal norm. There is also the concept of coupled norms ${ }^{38}$. Among the two-part concepts, two models of a legal norm are distinguished: the first, encompassing the hypothesis and disposition $\left(\mathrm{H}^{\oplus} \mathrm{D}\right)$, the second, composed of hypothesis and sanction $\left(\mathrm{H}^{\oplus} \mathrm{S}\right)$. A two-part norm in the setting Hypothesis ${ }^{\oplus}$ Disposition, sets out a situation in which, in the circumstances described in the hypothesis, the addressee of the norm should behave in a way compliant with the description comprised in the disposition of the norm. According to the second type of twopart norm, this time in the setting Hypothesis ${ }^{\oplus}$ Sanction, in the circumstances described in the hypothesis, the proper organ of the state should impose on the addressee of the law defined in the hypothesis the given sanction.

Generations of lawyers were taught, however, that a norm is composed of three elements-hypothesis, disposition and sanction-and they were taught that because, as slightly ironically stated by Józef Nowacki, "in the science of the law of the former Soviet Union, the three-part structure of the legal norm gained the most popularity and also was popularized in other socialist countries, and in Poland-mainly thanks to the Russian manual of the theory of state and law translated into Polish in $1951^{\prime \prime 39}$. The concept of a three-part structure of legal norm in the setting $\mathrm{H}^{\circledast} \mathrm{D} / \mathrm{S}$, assumes that when there is a legally relevant situation, that is, when the circumstances described in the hypothesis are fulfilled, the addressee of the norm should behave according to the model of conduct formulated in the disposition. Depending on whether one adheres to the norm according to the recommended model, a sanction (positive or negative) will be employed. Legal norms that do not possess a sanction within their structure are defined as leges imperfectae (imperfect norms) ${ }^{40}$. Some of the authors in the Polish science of law, such as Henryk Rot, Stanisław Ehrlich and Jerzy Kowalski, when faced with the question of whether a legal norm is composed solely of two elements (hypothesis and disposition) and that when deprived of a third element (sanction) may be effectively predicated as a designate of the notion of legal norm, adopted an orthodox, negative attitude, stating that every constituent element within the concept of the three-part structure of a legal norm is a compulsory element of every legal norm; consequently, they refused the attribute of

38 The following based on MORAWSKI, Lech. Wstęp do prawoznawstwa. Toruń: Dom Organizatora TNOIK, 1998, p. 58.

39 NOWACKI, Józef, TOBOR, Zygmunt. Wstęp do prawoznawstwa. Katowice: Naukowa Oficyna Wydawnicza, 1999, p. 67 and quoted titles.

40 For more on the creation of imperfect norms, see: JABŁOŃSKA-BONCA, Jolanta. Przesłanki stanowienia norm bez sankcji. "Ruch Prawniczy Ekonomiczny i Socjologiczny" (RPEiS) No. 4, 1984. 
legal norm all norms that were not composed of three elements: Hypothesis+ Disposition+Sanction ${ }^{41}$. Analysis of the content of legal norms indicates, however, that not all types of legal norms possess the third element (sanction), i.e., constitutional norms, and what is more, which will be discussed in more detail below, some norms of international public law are deprived of institutionalized sanctions, with no one (presently) questioning their legality.

In the professional literature, we may encounter opinions that, in reference to leges imperfectae, talk about a type of legal and factual possibility of "sanation" or the completion of the lack of a sanction-appropriation of a sanction from other provisions that formulate the sanction-and perceived jointly, they create the content of the decoded legal norm. Thus, we agree with Stanley L. Paulson's viewpoint, which claims that material norms are in a way secondary (as they are recreated from the content of the provisions of the law) and even if a singular provision does not have a sanction (for instance, a competence provision), in combination with other provisions that are decoded into a whole a legal norm will form and will be therefore completed by the sanction missing from the initial structure ${ }^{42}$. The lack of legal sanction, however, is not identical to a complete loss of control over addressees of imperfect norms but only of legal control, with social control maintained over the addressees by the impact of the dispersed sanctions foreseen in normative systems other than law.

\section{The Critical views on the concept of the three-part structure of a legal norm.}

The concept of the three-part structure of a legal norm has been questioned by Jerzy Lande, who demonstrated that in order to formulate a complete legal norm, it is sufficient indeed, to include two elements-hypothesis and disposition-and that sanction is "a separate norm [...] that has in its hypothesis enumeration of infringement of another norm, and in its disposition-assignment of the duty to the infringing subject, and of due entitlement to the second subject" ${ }^{\prime 3}$.

The concept of the coupled norms is based on the assumption that every legal norm is composed of two norms: a sanctioned norm $\left(\mathrm{H} 1^{\circ} \mathrm{D}\right)$ and a sanctioning norm $\left(\mathrm{H} 2^{\circ} \mathrm{S}\right)^{44}$. What this means is that given the circumstances/situation of

41 For more, see: ROT, Henryk. Kilka uwag o strukturze normy prawnej. „Państwo i Prawo” (PiP) 1957, Vol. 10, pp. 654, 655; EHRLICH, Stanisław. Przyczynek do problematyki normy i stosunku prawnego. „Państwo i Prawo” (PiP) 1956, Vol. 8-9, p. 389; KOWALSKI, Jerzy. Socjologiczny aspekt struktury normy prawnej. In EHRLICH, Stanisław (ed.). Studia z teorii prawa. Warszawa: Państwowe Wydawnictwo Naukowe, 1965, p. 281.

42 See: PAULSON, Stanley. An Empowerment Theory of Legal Norm. "Ratio Iuris" 1988/1, pp. $58-70$.

43 LANDE, Jerzy. Studia $z$ filozofii prawa. Warszawa: Państwowe Wydawnictwo Naukowe, 1959, p. 925.

44 It is important to point out the diversified terminology as far as the concept of conjugated 
legal relevance as defined in the hypothesis of the sanctioned norm (H1), it is the addressee of that rule who should (as a duty) behave according to a model of conduct described/comprised in the disposition of the sanctioned norm, and when upon infringement or lack of accomplishing the disposition-again, as defined in the conditions of the hypothesis of the sanctioning norm (H2) - the sanction (S) as defined in the sanctioning norm will be conferred in an institutionalized manner. Lande did not question the relationship between a legal norm and state constraint but stressed that sanctioned norms and sanctioning norms remain in relation through logical coupling, that is, that every sanctioned norm should have "its own" sanctioning norm. In conclusion, a rebours, it is impossible to construct sanctioning norms from legal provisions without sanctions (leges imperfectae), only so-called sanctioned norms. Lande's concept has been successively developed by Zygmunt Ziembiński, in whose opinion sanctioned and sanctioning norms remain in a far looser relationship of functional coupling ${ }^{45}$. The order to use constraint in case of infringement of a norm not only has to be expressed in that norm but it also is indispensable for the legal system to compose another norm encompassing such an order. A sanctioning norm in this approach is an auxiliary, hypothetical norm, activated only when the sanctioned norm is being infringed.

Other remarks or even reproaches were also formulated about the three-part structure of the legal norm. The first of the reproaches, made by Ryszard Sarkowicz and Jerzy Stelmach, concerns the semantic disorder among particular elements of the structure (H, D and S) of the legal norm within the concept in question. The authors of the reproach consider that "while the hypothesis belongs to the normative discourse (the norm indicates due behaviour prescribed by the disposition for the sake of the circle of addressees defined by the hypothesis), the sanction is an informative sentence, stating the consequences of non-fulfilment of the conduct prescribed by the disposition. By accepting then such a model of the structure, we would need to accept a rather suspicious connection of elements of the directive and descriptive discourse" 46 . The next reproach they formulated, conducted according to a reconstruction of the typical comprehension of an interpreter, goes as follows: if addressee A1 in situation B1 is supposed

norms is concerned, such as: sanctioned and sanctioning norms (i.e., LANDE, Jerzy. Studia $z$ filozofii prawa..., op.cit.,pp. 925-926); primal (basic) or material norms, and secondary norms or norms with a sanction (i.e., ROSS, Alf. On Law and Justice. London: Stevens \& Sons Limited, 1958, p. 209).

45 "'Legal norm' should be composed of two functionally conjugated (not identical with logically conjugated) norms of conduct. (...) It is easy to notice that those two conjugated norms of conduct have distinctive addressees, distinctive circumstances of use and wholly distinctive range of use of the sanction", ZIEMBIŃSKI, Zygmunt. Metodologiczne zagadnienia prawoznawstwa. Warszawa: Państwowe Wydawnictwo Naukowe, 1974, p. 216.

46 SARKOWICZ, Ryszard, STELAMCH, Jerzy. Teoria prawa. Monografie Wydziału Prawa i Administracji Uniwersytetu Jagiellońskiego. Kraków: Wydawnictwo Uniwersytetu Jagiellońskiego, 2001, p. 55. 
to behave in $\mathrm{C} 1$ manner, then addressee $\mathrm{A} 2$ (state organ) should behave with regard to A1 in C2 manner (sanction administrated to A1) and "demonstrates the incorrectness of a three-part structure of the legal norm while simultaneously indicating the correctness of another comprehension of the structure of the legal norm"47 as two norms coupled together.

Another author who questioned and rejected the three-part concept of legal norms as obsolete is Stanisław Kaźmierczyk, who also stated that in reference to certain types of legal norms, i.e., constitutional norms, the concept of coupled norms turns out to be inadequate because formulation of the sanctioning norm in the form of an order imposed on a state organ and having as an object an authentic, institutionalized reaction (administration of the sanction) for infringement of the sanctioning norm by its addressee would lead to the necessity to accept the conclusion contra legem that norms of the constitution are usually leges imperfectae. ${ }^{48}$

Kaźmierczyk, in his analysis of the phenomenon of legal sanction (in a manner distinctively different from the accepted and popularized theory of law to date), does not focus on the duty of the state organ to react to an infringement of the sanctioned norm, but clearly stresses the mandate of the organ to this reaction, by stating that a sanction is among the competence norms, not among the substantive norms that impose the duty of execution of conferred competences, that is, to administrate the sanction ${ }^{49}$. Kaźmierczyk's viewpoint encountered a positive reception from Stanisław Czepita, who stated that "even though this approach drifts away from the present scheme of perception of the sanctioning norm, it is worth praise, since it takes into account a significant, and so far, neglected, intuition that says that we can talk about a sanction for infringement of norm $\mathrm{N}$ when a given subject carries the competence to react to the infringement of that norm and uses it, even without being forced to it by duty"50.

The totality of the debate between the supporters of one concept or the other of the structure of a legal norm (that is, the three-part structure and the concept of coupled norms) and the role of the sanction, was the most accurately summed up and, in a way, concluded by Maria Borucka-Arctowa, who assessed that these concepts are not contradictory and that both constitute a rule for constructing legal norms from the provisions, which makes the choice of one of them neutral (she considers it to be a sort of convention) because, anyway, it doesn't modify

47 Ibidem, pp. 55-56.

48 CZEPITA, Stanisław. Konstytucja a teoria prawa. „Ruch Prawniczy, Ekonomiczny i Socjologiczny” (RPEiS), Year LXII, Vol. 2, 2000, p. 188.

49 KAŹMIERCZYK, Stanisław. Sankcja Konstytucji jako zagadnienie metodologiczne. In BATOR, ANDRZEJ (ed.). Z zagadnień teorii i filozofii prawa. Konstytucja. Wrocław: Wydawnictwo Uniwersytetu Wrocławskiego,1999, pp. 14-15.

50 CZEPITA, Stanisław. Konstytucja a teoria prawa...,op.cit., p. 188. 
the content of the law but only the systematization of the orders, interdictions, permissions, conditions to apply them and sanctions ${ }^{51}$.

\section{International law as lex imperfecta.}

According to some authors, the fact that international public law, also known as law of nations, hasn't developed a system of institutionalized sanctions ensuring observance of its norms results from the fact that it constitutes in its totality quasi law, that is, a sensu stricto collection of norms of the type leges imperfectae. In Franiciszek Ryszka's view, the mistake committed in the reflection on international law and in its study is rooted in this statement: international law is still an imperfect law (lex imperfecta) ${ }^{52}$. The mistake committed the most frequently by lawyers not expert in international public law unjustifiably and incorrectly transfer the apparatus of notions with precisely assigned significance straight from the theory of domestic (in this case, Polish) law into the sphere of research on public international law. International law is shaped as a decentralized structure, within which the question of the execution of behaviours complying with its principles and rules, including those concerning order and respect of values, but also self-defence, belong to the duties of the subjects of that law-members of international society; despite this decentralized character, international law has not been deprived of the attribute of law ${ }^{53}$. International law disposes of a series of sanctions that, even though plausible to use or enforce at any time, formallyde iure-exist and potentially are able to influence the behaviour of particular members of the international community, do not always translate into reality. This potential, however, that is, the principle stating that states and other subjects responsible for breaking international law must envisage, at least in theory, painful consequences, is one of the reasons for international law to be considered real law ${ }^{54}$.

Amongst the norms of international law, we can encounter more and more frequently norms that nevertheless carry sanctions. This is a result of the modification that takes place in the characteristics of international law on two lev-

51 BORUCKA-ARCTOWA, Maria, WOLEŃSKI, Jan. Wstęp do prawoznawstwa. Kraków: Wydawnictwo Uniwersytetu Jagiellońskiego, 1998, p. 79.

52 RYSZKA, Franciszek. Pamiętnik inteligenta: Dojrzewanie vol. 1. Warszawa: Polska Oficyna Wydawnicza "BGW", 1994, p. 15.

53 As retaliatory means used in the guise of sanctions by international public law, we can indicate, i.e., represalia. For more, see: SZWEDO, Piotr. Środki odwetowe w prawie Światowej Organizacji Handlu. Warszawa: Oficyna a Wolters Kluwer (a business), 2008, p. 19. See also RYSZKA, Joanna. Praktyka stosowania sankcji międzynarodowych $w$ ramach ONZ. „Kwartalik Prawa Publicznego" rok V, nr 3/2005, pp. 9-40.

54 SIMMA, Bruno. Self-contained regimes. Netherlands Yearbook of International Law 1985, No. 16, p. 135. See also SIMMA, Bruno, PULKOWSKI, Dirk. Of Planets and the Universe: Self-contained Regimes in International Law. "The European Journal of International Law" Vol. 17 no.3. EJIL 2006, pp. 483-529. [online]. Available at: http://www.ejil.org/ pdfs/17/3/202.pdf, Accessed: 08. 09. 2017. 
els-in the structure of the sources of law and in its goals and functions. In the first level, international public law is submitted to the process of constitutionalisation (what can be described as the evolution from a multi-centric flat structure to a more protuberant form). In the second level, according to Lech Morawski, international public law heads towards a break, which he characterizes as "Kant's turn" and which can be simply described as passing in the domain of international law from the law of states to the law of states and nations-an understanding of international law in which the law is treated above all as an instrument of coordination of relations between states in the way bi- or multilateral contracts that the states adhere to or not, instead of to a comprehension in which international law also becomes an instrument of protection of goods common to the entire international community. Perceived in this way, international law regulates not only relations between states but also relations between states and citizens and their organisations" ${ }^{\prime 55}$. The admonished protection of the common goods of the international community, to a greater and greater extent, is carried out through making, applying and enforcing concentrated sanctions while also applying dispersed sanctions that don't need to be applied directly in order to reach the intended result, as the very prospect of the sanctions happens to be sufficient (to various and, unfortunately, not always the adequate degree) in order to warn given actors of international law of unwanted behaviours from the point of view of the international community. In practice, the auxiliary aspect of sanctions finds its confirmation, as a sanction has not always been automatically and immediately applied in case of infringement of a legal duty, since launching a sanction may require a specific legal action on behalf of another entitled subject of international law. It is necessary, though, to notice that "in some cases, it is possible to find a sanctioning norm for infringement of a sanctioning norm, that is, a norm that orders to administer a sanction for non-administration of a sanction that should have been administered by state officials obliged to do so in case of a confirmation of infringement of a sanctioning norm. Eventually, however, the chain of following sanctioning norms accumulates in a norm, the infringement of which is only penalized by political or moral responsibility, not a legal sanction" ${ }^{\prime \prime}$.

\section{Conclusion.}

To sum up, the effectiveness, efficiency and purposefulness of the law is not completely nor exclusively conditioned by the existence and type of legal constraint. Unfortunately, also today "the fact of the existence of sanctions as well as their great significance in the functioning of the systems of law make many theoreticians believe that constraint is a constitutive feature of the very notion of

55 MORAWSKI, Lech. Suwerenność i prawo międzynarodowe-od prawa państw do prawa ludów. „Forum Prawnicze” No. 1 (3), 2011, pp. 13-14.

56 REDELBACH, Andrzej, WRONKOWSKA, Sławomira, ZIEMBIŃSKI, Zygmunt. Zarys teorii państwa i prawa. op.cit., p. 91. 
the law. They, therefore, perceive constraint almost as the basis for the enforcement of the law. Meanwhile, the social reality of the phenomenon of the force of law is quite different" ${ }^{\prime \prime}$.

In conclusion, it is important to note that an interesting type of legal sanction in the Polish legal order is positive sanctions. It is true that their role is not large in whole legal system but sometimes they are the more effectiveness factor of human motivation to legal behavior and more effectiveness factor of creating and protecting social and legal order than negative sanctions and legal procedure of punishment. For this reason, both the national legislator and the actors of the international community should all revise their own philosophy of shaping the national and supranational legal order. Negative sanctions are currently less effective and at the same time more and more expensive. Maybe the effectiveness and effectiveness of the legal protection of politically organized communities will depend on a change in the understanding of the role of law as a factor in bringing about social order and reconciling the particular conflicting interests of individuals by rewarding for the submission of the law. However, representatives of the economic analysis of the law can rightly claim that prizes are de facto less expensive than penalties for both the legal system itself and the economy as a whole, especially on the supranation level.

\section{References}

BORUCKA-ARCTOWA, Maria, WOLEŃSKI, Jan. Wstęp do prawoznawstwa. Kraków: Wydawnictwo. Uniwersytetu Jagiellońskiego w Krakowie, 1998.

BROŻEK, Bartosz, BROŻEK, Anna, STELMACH, Jerzy. Fenomen normatywności. Kraków: Copernicus Center Press, 2013.

CESARZ, Zbigniew. Sankcje międzynarodowe. In ŁOŚ-NOWAK, Teresa, FLORCZAK, Agnieszka (eds.). Encyklopedia politologii. Tom V Stosunki Międzynarodowe. Warszawa: Oficyna Wolters Kluwer business, 2010.

CHAUVIN, Tatiana, STAWECKI, Tomasz, WINCZOREK, Piotr. Wstęp do prawoznawstwa. Warszawa: CH Beck, 2014.

COOTER, Roger, ULEN, Thomas. Law and Economics. Pearson Addison Wesley, BostonSan Francisco-New York-London-Toronto-Sydney-Tokyo-Singapore-MadridMexico City-Munich-Paris-Cape Town-Hong Kong-Montreal, 2008.

CZEPITA, Stanisław. Konstrukcje teoretycznoprawne Czesława Znamierowskiego. Poznań: Wydawnictwo Naukowe UAM, 1988.

CZEPITA, Stanisław. Konstytucja a teoria prawa. „Ruch Prawniczy, Ekonomiczny i Socjologiczny" (RPEiS) Rok LXII — zeszyt 2- 2000.

DUFF, Antony, R. Karanie obywateli. „Ius et Lex” 2006, Nr 1.

DUTKIEWICZ, Paweł. Powinności i sankcje. In Etyka zarys. Kraków: Uniwersytet Jagielloński. Instytut Filozofii. Zakład Etyki. Wydawnictwo Uniwersytetu Jagiellońskiego w Krakowie, 1992.

57 IZDEBSKI, Zygmunt. Teoria państwa i prawa. op.cit., p. 173. 
DWORKIN, Ronald. Biorąc prawa poważnie. Warszawa: Państwowe Wydawnictwo Naukowe, 1998.

DZIEDZIAK, Wojciech. Sankcje prawne. In SOKÓ£, Wojciech, DZIEMIDOK-OLSZEWSKA, Bożena. Encyklopedia politologii. Vol. 2 Instytucje i systemy polityczne. Warszawa: Oficyna a Wolters Kluwer business, 2012.

DZIEDZIAK, Wojciech. Wplyw sankcji prawnych i moralnych na skuteczność prawa. „Studia Iuridica Lublinensia", Vol. XXIV, 1, 2015.

EHRLICH, Stanisław. Przyczynek do problematyki normy i stosunku prawnego. „Państwo i Prawo" (PIP) 1956, z. 8-9.

FILIPEK, Józef. Sankcja prawna w prawie administracyjnym. „Państwo i Prawo” (PIP) nr $12 \mathrm{z} 1963$.

GARNER, Bryan (ed.). Black's Law Dictionary. Ninth edition. United States: WEST A Thomson Reuters business, 2009.

GREEN, Michael Steven. Hans Kelsen and the logic of legal systems. "Alabama Law Review" Vol. 53 No.2, 2003.

GRYNIUK, Anna. Przymus prawny: studium socjologiczno-prawne. Toruń: Wydawnictwo Uniwersytetu Mikołaja Kopernika w Toruniu,1994.

GRYNIUK, Anna. Sankcja prawna a prawny przymus. In SKĄPSKA, Grażyna, CZAPSKA, Janina, DANIEL, Krystyna, GÓRSKI, Jakub, PAŁECKI Krzysztof (eds). Prawo w zmieniającym się społeczeństwie. Ksiegga Jubileuszowa Profesor Marii Boruckiej-Arctowej. Kraków: Wydawnictwo Adam Marszałek i Uniwersytet Jagielloński, 1992.

GRZYBOWSKI, Stefan. Dzieje prawa. Opowieść, refleksje, rozważania. WrocławWarszawa-Kraków: Wydawnictwo Zakład Narodowy im. Ossolińskich, 1981.

IZDEBSKI, Zygmunt. Teoria państwa i prawa. Warszawa: Akademia Teologii Katolickiej, 1975.

JABŁOŃSKA-BONCA, JOLANTA. Przesłanki stanowienia norm bez sankcji. „Ruch Prawniczy, Ekonomiczny i Socjologiczny" RPEiS Nr 4 z 1984 r.

KAŹMIERCZYK, Stanisław. Sankcja Konstytucji jako zagadnienie metodologiczne. In BATOR, Andrzej. (ed.). Z zagadnień teorii i filozofii prawa. Konstytucja. Wrocław: Wydawnictwo Uniwersytetu. Wrocław 1999.

KELSEN, Hans. Pure Theory of Law. Berkeley-Los Angeles: University of California Press, 1970.

KOJDER, Andrzej. Godność i siła prawa. Warszawa: Oficyna Naukowa, 2001.

KOWALSKI, Jerzy. Socjologiczny aspekt struktury normy prawnej. In EHRLICH, Stanisław (ed.). Studia $z$ teorii prawa. Warszawa: Państwowe Wydawnictwo Naukowe, 1965.

LANDE, Jerzy. Studia $z$ filozofii prawa. Warszawa: Państwowe Wydawnictwo Naukowe,1959.

MAKAREWICZ, Juliusz. Prawo karne ogólne. Lwów 1914.

MARSHALL, Gordon. (ed.), TABIN, Marek. (ed.). Słownik socjologii i nauk społecznych. Warszawa: Państwowe Wydawnictwo Naukowe, 2008.

MORAWSKI, Lech. Suwerenność i prawo międzynarodowe- od prawa państw do prawa ludów. „Forum Prawnicze” Nr 1 (3), 2011. 
MORAWSKI, Lech. Wstęp do prawoznawstwa. Toruń: Dom Organizatora TNOIK, 1998.

NOWACKI, Józef, TOBOR, Zygmunt. Wstęp do prawoznawstwa. Katowice: Naukowa Oficyna Wydawnicza, 1999.

OPAŁEK, Kazimierz. Z zagadnień teorii prawa i teorii nauki Leona Petrażyckiego: studia opracowane dla upamiętnienia stulecia urodzin. Warszawa: Państwowe Wydawnictwo Naukowe, 1969.

PAŁECKI, Krzysztof. Prawoznawstwo zarys wykładu. Prawo w porzadku społecznym. Warszawa: Wydawnictwo Difin, 2003.

PAŁECKI, Krzysztof. Społeczne opinie o prawie i jego sadowym stosowaniu w dziedzinie stosunków rodzinnych. In BORUCKA-ARCTOWA, Maria. Poglady społeczeństwa polskiego na stosowanie prawa. Wrocław: Wydawnictwo Zakład Narodowy im. Ossolińskich, 1978.

PAULSON, Stanley, L. An Empowerment Theory of Legal Norm. "Ratio Iuris” 1988/1.

PENO, Michał. Filozoficzne podstawy karania-uzasadnienie istnienia kary we współczesnych społeczeństwach demokratycznych. In NAWROT, Oktawian, SYKUNA, Sebastian, ZAJADŁO, Jerzy (eds.). Konwergencja czy dywergencja kultur i systemów prawnych. Warszawa: Wydawnictwo CH Beck, 2012.

REDELBACH, Andrzej. WRONKOWSKA, Sławomira. ZIEMBIŃSKI, Zygmunt. Zarys teorii państwa i prawa. Warszawa: Państwowe Wydawnictwo Naukowe, 1994.

ROSS, Alf. On Law and Justice. London: Stevens \& Sons Limited. 1958.

ROT, Henryk. Kilka uwag o strukturze normy prawnej. „Państwo i Prawo” (PIP) 1957, z. 10.

RYSZKA, Franciszek. Pamiętnik inteligenta: Dojrzewanie. Tom 1. Warszawa: Polska Oficyna Wydawnicza "BGW", 1994.

RYSZKA, Joanna. Praktyka stosowania sankcji międzynarodowych $w$ ramach ONZ. „Kwartalik Prawa Publicznego” rok V, nr 3/2005.

SARKOWICZ, Ryszard, STELAMCH, Jerzy. Teoria prawa. Monografie Wydziału Prawa i Administracji Uniwersytetu Jagiellońskiego. Kraków: Wydawnictwo Uniwersytetu Jagiellońskiego, 2001.

SEIDLER, Grzegorz, Leopold, GROSZYK, Henryk, PIENIĄŻEK, Antoni. Wprowadzenie do nauki o państwie i prawie. Lublin: Wydawnictwo Uniwersytetu Marii Curie Skłodowskiej, 2003.

SIMMA, Bruno. Self-contained regimes. Netherlands Yearbook of International Law 1985, No. 16.

SIMMA, Bruno, PULKOWSKI Dirk. Of Planets and the Universe: Self-contained Regimes in International Law. "The European Journal of International Law" Vol. 17 no.3. EJIL 2006. (http://www.ejil.org/pdfs/17/3/202.pdf).

SOŁTYSIŃSKI, Stanisław, SZLĘZAK, Andrzej. Profesor dr Zbigniew Radwański (19242012). „Studia Prawa Prywatnego”, Rocznik 7, Zeszyt 1(28) 2013.

SZWEDO, Piotr. Środki odwetowe w prawie Światowej Organizacji Handlu. Warszawa: Oficyna a Wolters Kluwer a business, 2008.

WRÓBLEWSKI, Jerzy. Krytyka normatywistycznej teorii prawa i państwa Hansa Kelsena. Warszawa: Państwowe Wydawnictwo Naukowe, 1955. 
ICLR, 2017, Vol. 17, No. 2.

ZIEMBIŃSKI, Zygmunt. Metodologiczne zagadnienia prawoznawstwa. Warszawa: Państwowe Wydawnictwo Naukowe, 1974.

ZIEMBIŃSKI, Zygmunt. Problemy podstawowe prawoznawstwa. Warszawa: Państwowe Wydawnictwo Naukowe, 1980.

ZNAMIEROWSKI, Czesław. Podstawowe pojęcia teorii prawa, cz. I. Układ prawny i norma prawna, Poznań-Warszawa-Toruń 1934. 